\title{
Analysis of Late Preterm Births: Are There any Differences Among Etiologic Subgroups in Terms of Neonatal Outcomes?*
}

\author{
Geç Preterm Doğumların Analizi: Yenidoğan Sonuçları Açısından Etyolojik Altgruplar Arasında Farklılıklar Var mı?
}

Egemen Tolunay'1, Ali Gemici', Ömer Dai', Yavuz Emre Șükür1', Korhan Kahraman1, Feride Söylemez ${ }^{1}$, Acar Koç ${ }^{1}$

Ankara Universitesi Tıp Fakültesi, Kadın Hastalıkları ve Doğum 1Mart 2013 Sth

3 Sth South East European Congress of Perinatal Medicine poster olarak sunulumuștur.
Received : July 15,2015 • Accepted: June 23,2016

Iletișim.

Dr.Egemen Tolunay

E-posta: harunegementolunay@gmail.com GSM: 05557736303

Vakfıkebir Devlet Hastanesi Kadın Hastalıkları ve Doğum Bölümü Vakfıkebir / TRABZON

Aim: To evaluate the neonatal outcomes of late preterm births (LBPs) according to etiologic subgroups and to evaluate if there is any association between birth indication and neonatal morbidity in late preterm births.

Material and Method: Singleton pregnancies delivered between $34^{0 / 7}-36^{6 / 7}$ weeks ( 34 weeks and 36 weeks 6 days of pregnancy) during a 3-year period at a tertiary care university hospital were studied. Indications for delivery were classified as either spontaneous or inducted with medical indication. Inducted with medical indication LPBs were categorized as either evidence-based (EB) (eg. severe preeclampsia/eclampsia, HELLP syndrome, abnormal fetal test, placenta previa or placental abruption with vaginal bleeding, and unstable/worsening medical conditions) or non evidence-based (NEB) (mild preeclampsia, intrauterine growth restriction with normal fetal test, oligohydramnios with normal fetal test, and mild/stable medical conditions).

Results: There were 179 LPBs; 118 (66\%) spontaneous and 61 (34\%) inducted with medical indication. 76\% of spontaneous LPBs were preterm labor with intact membranes and $24 \%$ were premature preterm rupture of membranes. $52 \%$ of inducted with medical indication LPBs were EB and $48 \%$ were NEB. The frequencies of neonatal intensive care unit (NICU) admissions were similar between the groups. The only significant difference among indications was infection rates in NICU (7\% in the spontaneous vs. $33 \%$ in the inducted with medical indication group; $P<0.001)$. Women with NEB deliveries were significantly older $(31,6$ vs. 27,9; $P=0,010)$. NICU admission rates were significantly higher in the EB group, when compared to the NEB group ( $40 \%$ vs. $7 \% ; P=, 003$ )

Conclusion: Inducted with medical indication LPBs consist of almost one third of all LPBs and accompany high rates of neonatal infections. Also among inducted with medical indication LPBs, neonatal morbidity is higher in cases with EB indications, when compared with the NEB subgroup.

Key Words: Late Preterm Births, latrogenic, Spontaneous

Amaç: Geç preterm doğumların etyolojik subgruplara göre yenidoğan sonuçlarının analizi ve geç preterm doğumlarda doğum endikasyonu ve yenidoğan morbiditesi arasında ilișki olup olmadığının değerlendirilmesi.

Gereç ve Yöntem: Bir üniversite hastanesinde meydana gelen $34^{0 / 7}-36^{6 / 7}$ hafta arası (34 hafta ve 36 hafta 6 gün gebelikler) doğumlar 3 yıllık bir süre için incelendi. Doğum endikasyonları spontan ve tıbbi endikasyonla indüklenen doğumlar olarak sınıflandırıldı. Tıbbi endikasyonla indüklenen geç preterm doğumlar kanıta dayalı olan (ciddi preeklampsi, eklampsi, HELLP Sendromu, anormal fetal test, plasenta previa, kanamayla birlikte plasenta dekolmanı, stabil olmayan kötüye giden tıbbi durumlar) ve kanıta dayalı olmayan (hafif preeklampsi, normal fetal testlere eșlik eden intrauterin gelișme geriliği, normal fetal testlere eșlik eden oligohidramnioz, hafif stabil tıbbi durumlar) endikasyonlar olarak değerlendirildi.

Bulgular: Toplam geç preterm doğum sayısı 179 olarak bulundu. $118^{\prime} \mathrm{i}$ spontan, 61'i tıbbi endikasyonla indüklenen doğumlardı. Spontan geç preterm doğumların \%76'sında membranların intakt, \%24'ünde ise rüptüre olduğu bulundu. Tıbbi endikasyonla indüklenen geç preterm doğumların $\% 52$ 'si kanıta dayalı endikasyon ile doğurtulurken, \%48'I ise kanıta dayalı olmayan endikasyonlar ile doğurtuldu. Yenidoğan yoğun bakım ihtiyacı her 2 grupta da benzerdi. Yenidoğan yoğun bakıma yatıș endikasyonları arasında tek anlamlı fark enfeksiyon oranlarında izlendi (\%7 spontan grup, \%33 tıbbi endikasyonla indüklenen grup $\mathrm{p}<0,001$ ). Kanıta Dayalı Olmayan doğum grubundaki kadınlar, Kanıta Dayalı grubundaki kadınlara gore anlamlı olarak daha yașlı olarak hesaplandı ( 31.6 vs. $27.9 ; p=0,01)$. Yenidoğan yoğun bakım yatıș oranları kanıta dayalı olan grupta anlamlı olarak daha yüksekti. $(40 \%$ vs. $7 \% \mathrm{p}=0.003)$

Sonuç: tıbbi endikasyonla indüklenen geç preterm doğumlar olguların $1 / 3$ ünü olușturmakta ve yüksek neonatal enfeksiyon oranına sahip olarak izlendi. Aynı șekilde neonatal morbiditenin dé kanıta dayalı grupta daha yüksek olduğu görülmüștür.

Anahtar Sözcükler: GeçPreterm Doğum, lyatrojenik, Spontan

Preterm birth is delivery before $37^{\text {th }}$ gestational week and late preterm birth $(\mathrm{LPB})$ is defined as delivery between $34^{0 / 7}$ and $36^{6 / 7}$ weeks of gestation (1). Late preterm births constitute a significant portion of preterm births and the incidence in the United States has been reported as $8.1 \% \quad(2,3)$. Although many of them are not considered a high-risk category, late 
preterm new-borns have a significant burden to society due to increased rates of short and long-term morbidity and mortality (4). Spontaneous preterm birth and premature rupture of membranes are the most common reasons of LPBs (5). However, a considerable amount of them are inducted births (5). Inducted with medical indication LPBs are categorized as either evidence-based (EB) (eg. severe preeclampsia/ eclampsia, HELLP syndrome \{hemolysis, elevated liver enzyme levels, and low platelet levels\}, abnormal fetal testing, placenta previa or abruptio placenta with vaginal bleeding, and unstable/worsening medical conditions) or non evidencebased (NEB) (mild preeclampsia, intrauterine growth restriction with normal fetal testing, oligohydramnios with normal fetal testing, and mild/stable medical conditions) (6).

Late preterm births are associated with increased respiratory distress syndrome, transient tachypnea of newborn, and requirement for ventilatory support as well as intraventricular hemorrhage, necrotizing enterocolitis, sepsis, hyperbilirubinemia and feeding difficulties. Not only morbidity is higher in these cases, but also late preterm newborns were found to be under increased risk for mortality compared to their term counterparts (3). Therefore, substantial morbidity and mortality associated with LPBs necessitate a better understanding of this entity and identification of risk factors. Thereby, developing more effective management modalities can be feasible.

The aim of the present study was to evaluate the neonatal outcomes of late preterm births according to etiologic subgroups and to evaluate if there is any association with birth indication and neonatal morbidity in late preterm births.

\section{Material and methods}

This retrospective study was conducted in a university based tertiary care hospital in accordance with the principles of the
Declaration of Helsinki and approved by the Institutional Review Board of university. Records of all singleton pregnancies delivered between $34^{\circ / 7}$ and $36^{6 / 7}$ gestational weeks between January 2011 and December 2013 in the department of obstetrics and gynecology were reviewed. Indications for delivery were classified as either spontaneous or inducted with medical indication as described in the literature. Inducted with medical indication LPBs were categorized as either EB (eg, severe preeclampsia/eclampsia, HELLP syndrome, abnormal fetal testing, placenta previa or abruptio placenta with vaginal bleeding, and unstable/ worsening medical conditions) or NEB (mild preeclampsia, intrauterine growth restriction with normal fetal testing, oligohydramnios with normal fetal testing, and mild/stable medical conditions) (6).

Data were analyzed using the Statistical Package for Social Sciences 20.0 for Windows (SPSS Inc., Chicago, IL). Parametric tests (Independent-samples t-test and posthoc Tukey test) were applied to data of normal distribution and non-parametric tests (MannWhiney U-test and Kruskal-Wallis Test) were used for data of questionably normal distribution. Continuous data were presented as either mean \pm standard deviation or median-interquartile range (minimummaximum). All differences associated with a chance probability of 0.05 or less were considered statistically significant.

\section{Results}

There were 179 late preterm births, of which $118(66 \%)$ spontaneous and 61 $(34 \%)$ inducted with medical indication. Seventy six percent of spontaneous LPBs were preterm labor with intact membranes and $24 \%$ were premature preterm rupture of membranes. Of inducted with medical indication LPBs, 52\% had EB indications and $48 \%$ occurred in conjunction with NEB indications. The frequencies of neonatal intensive care unit (NICU) admission were same $(24.5 \%)$ in both groups. The only significant difference among indications was infection rates in NICU $(7 \%$ in the spontaneous $v s$. $33 \%$ in the inducted with medical indication group; $P<0.001)$. Also, admission rates for NICU were remarkably higher in the EB group compared to the NEB group ( $40 \%$ vs. $7 \%$, respectively; $\mathrm{p}=0.003)$.

\section{Discussion}

The aim of the current study was to analyse the neonatal outcomes of LPBs with spontaneous and medical indications. Our results indicated that infection rates were higher in iatrogenic LPBs and admission for NICU was higher in the LPBs occurring due to inducted with evidence based medical indications.

In spite of the recent decline in rates of LPBs, incidence and subsequent consequences still remain a substantial concern. It has been postulated that infants with LPB are under risk for suboptimal long-term outcomes, therefore timely assessment and longterm follow-up are essential. Identification of individuals under risk and providing educational facilities on these topics is crucial in alleviation of the burdens due to LPBs (7).

For LPBs, instability of temperature and respiratory distress syndrome may be detected during perinatal hospitalization or conditions like hyperbilirubinemia and feeding difficulties can necessitate readmission (7). Hence, motivation and efforts are increased to lower the frequency of LPBs and to achieve more acceptable rates of morbidity and mortality.

The indication for intensive care unit stay for the LP newborn is determined with respect to the clinical risk factors or disease. Moreover, factors that affect the decision to admit the LP newborn to a NICU include the level of care facilities available, preferences of the provider and practice of the institution according to gestational age or birth weight thresholds $(8,9)$.

However, there is lack of data for reduction of LPB rates in the current evidence based knowledge. No bulletins or committee reports exist on the 
steps to be taken and multiple complex causes underlying LPBs make the situation more challenging. Complexity and heterogeneity of underlying causes, establishing a simple preventive strategy is impossible. Hopefully, reports indicate that despite the fact that rates of preterm birth and LPBs are increased, perinatal mortality rate is decreased for LPBs (10).

Intensive care requirements of late preterm infants are reported higher than term infants (11). A study by Raju et al. (12) showed a NICU admission rate of $51 \%$ in LP infants. In our study, rate of need for NICU was found to be $24.5 \%$. In this aspect, there was no difference between spontaneous and inducted with medical indication groups.

Owing to the immature immune system and defense mechanisms in preterm infants, they are more vulnerable to infections. Infection rate in late preterm infants has been reported as high as $15 \%$ in the literature (13). In

\section{REFERENCES}

1. Kramer MS. Later preterm birth: appreciable risks, risking incidence. J Pediatr 2009;154:159-160

2. Goldenberg RL, Culhane JF, Iams JD et al. Preterm birth 1. Epidemiology and causes of preterm birth. Lancet 2008; 371:75-84.

3. Martin JA, Kirmeyer S, Osterman M et al. Born abit too early: recent trends in late preterm births. NCHS Data Brief 2009; 24:1-8.

4. Gyamfi-Bannerman C. Late preterm birth: management dilemmas. Obstet Gynecol Clin North Am 2012;39:35-45.

5. Taylor HG. Outcomes of late preterm birth: who is at risk and for what? Am J Obstet Gynecol 2012;206:181-182.

6. Gyamfi-Bannerman C, Fuchs KM, Young $\mathrm{OM}$ et al. Nonspontaneous late preterm our study, infection rates were $7 \%$ in the spontaneous and $33 \%$ in the iatrogenic groups. Neonatal infection rate in inducted with medical indication group seems to be higher than that reported in the literature. Gyamfi-Bannerman et al. (4) reported that of the 2693 late preterm deliveries, $32.3 \% \quad(872 / 2693)$ were iatrogenic; $56.7 \%$ were delivered for NEB indications. Neonates in the EB group were more likely to be admitted to the $\mathrm{NICU}(56.0 \%$ vs. $31.0 \%$, $\mathrm{p}<0.001)$. In our study NICU admission rates were significantly higher in the EB group, too. It is noteworthy that $\mathrm{EB}$ indications are more likely to constitute risk factors for NICU admission in our series. In this retrospective study, we found that $48 \%$ and $52 \%$ of all late preterm births occurred due to NEB and EB indications, respectively. Our results demonstrated that the modes of delivery were not different between the groups. In recent literature, Morais et al. (14) have reported that delivery indications of 524 late preterm births

birth: etiology and outcomes. Am J Obstet Gyneco 2011;205:451-456.

7. Samra HA, McGrath JM, Wehbe M. An integrated review of developmental outcomes and late-preterm birth. J Obstet Gynecol Neonatal Nurs 2011;40:399-411.

8. Aliaga S, Boggess K, Ivester TS et al. Influence of neonatal practice variation on outcomes of late preterm birth. Am J Perinatol 2014; 31:659-666.

9. Aliaga S, Price W, McCaffrey M et al. Variation in late-preterm deliveries: a physician survey. J Perinatol 2013;33:347-351.

10. Chauhan SP. Late preterm births: irreducible because $\mathrm{E}=\mathrm{mc}^{2}$. Am J Obstet $\mathrm{Gy}$ necol 2011;204:459-460.

11. McIntire D, Leveno KJ. Neonatal mortality and morbidity rates in late preterm due to NEB and EB causes were 25\% and $75 \%$, respectively.

Main limitations of this study are retrospective design and relatively small sample size. Differences in participant characteristics, roles of confounding factors such as environment, metabolism and ethnicity, definition of terms such as 'evidence based' and 'non-evidence based' and restrictions attributed to methodology must be remembered during interpretation of our results.

To conclude, findings of the present study imply that iatrogenic LPBs comprise approximately one third of all LPBs and are accompanied with high rates of neonatal infection. Among inducted with medical indication LPBs, neonatal morbidity is higher in cases with EB indications compared to patients with NEB indications.

births compared with births at term. Obstet Gynecol 2008;111:35-41.

12. Raju TN, Higgins RD, Stark AR et al Optimising care and outcome for late preterm infants: a summary of the workshop sponsored by the national institute of child health and human development. Pediatrics 2006;118:1207-1214.

13. Tomashek KM, Shapiro-Mendoza CK Davidoff MJ et al. Differences in mortality between late-preterm and term singleton infants in the United States, 19952002. J Pediatr 2007;151:450-456.

14. Morais M, Mehta C, Murphy Ket al. How often are late preterm births the result of non-evidence based practices: analysis from a retrospective cohort study at two tertiary referral centres in a nationalised healthcare system. BJOG 2013; 120:15081514. 
